\title{
ANALISIS METAFORA PENDIDIKAN DAN PERKEMBANGAN SOSIOEMOSIONAL TOKOH UTAMA FILM "BEAUTY AND THE BEAST" VERSI LIVE-ACTION
}

\author{
Prima Dona Hapsari \\ Program Studi Seni Musik, Fakultas Seni Pertunjukan, Institut Seni Indonesia, Yogyakarta \\ Jalan Parangtritis Km 6,5 Bantul, Yogyakarta \\ No.Hp.: 08122763884,E-mail: dona.hapsari@gmail.com
}

\author{
F.A. Wisnu Wirawan \\ Program Studi Ilmu Komunikasi, Sekolah Tinggi Ilmu Komunikasi dan Sekretari Tarakanita \\ Kompleks Billy \& Moon, Pondok Kelapa, Jakarta Timur 13450 \\ No.Hp.: 08159381905, E-mail: wisnu.frans@gmail.com
}

\begin{abstract}
ABSTRAK
Penelitian ini dilatarbelakangi oleh adanya perbedaan konsep pendidikan yang terjadi di struktur sosial masyarakat Perancis pada abad ke-18. Berdasarkan hal tersebut, penelitian ini bertujuan untuk memberikan analisis metafora pendidikan dan perkembangan sosioemosional sang tokoh utama film "Beauty and the Beast" versi live-action, Belle. Jenis penelitian ini adalah kualitatif deskriptif, dengan studi kepustakaan mengambil teori-teori utama, yakni teori metafora pendidikan dan perkembangan sosioemosional. Hasil penelitian menunjukkan bahwa metafora pendidikan digambarkan secara jelas oleh tokoh utama dalam kaitannya dengan buku, perpustakaan, pendampingan membaca, dan book discussion. Hal ini pada akhirnya membawa pengaruh baik bagi kondisi masyarakat saat itu. Perkembangan sosioemosional tokoh utama berkaitan pula dengan mikrosistem, mesosistem, dan makrosistem yang menjadi satu rangkaian proses perkembangan aspek psikososialnya, yaitu kepercayaan, otonomi, inisiatif, rajin, identitas, dan keintiman.
\end{abstract}

Kata kunci: metafora pendidikan, perkembangan sosioemosional, konsep diri, "Beauty and the Beast" versi live-action

\section{ABSTRACT}

Analysis on Educational Metaphors and Socio-emotional Development of Live-Action Version "Beauty and the Beast" Main Character. This research was encouraged by the differences in the concept of education that occurred in the social structure of French society in the 18th century. This study aims to provide an analysis on educational metaphors and socio-emotional development of live-action version "Beauty and the Beast", the main character, Belle. This research is a qualitative descriptive one, applying the theory of educational metaphor and socio-emotional development. The results showed that the main character clearly described the educational metaphor by doing many activities in relation to books, libraries, reading assistance, and book discussion. These brought good influence to the condition of the community at that time. Microsystems, mesosystems, and macrosystems related the main character to socio-emotional development. They led to be a series of processes in the development of psychosocial aspects, namely trust, autonomy, initiative, diligence, identity, and intimacy.

Keywords: educational metaphors, socio-emotional development, self-concept, live-action version "Beauty and the Beast" 


\section{PENDAHULUAN}

"Beauty and the Beast" merupakan sebuah cerita rakyat di Perancis yang memberikan gambaran kehidupan para gadis Perancis pada masa abad ke-18. Selain itu, cerita dongeng ini pun memberikan konsep akan sebuah perjodohan yang ada di masyarakat pada masa itu. Mengacu pada cerita aslinya, "Beauty and the Beast" banyak mengundang respons dan memberikan pandangan terhadap kehidupan sosial pada abad ke-18, terutama mengenai bagaimana konflik-konflik timbul karena adanya kesenjangan kelas sosial di masyarakat. Berangkat dari dongeng sepanjang masa "Beauty and the Beast", produsenprodusen film dunia mengangkat cerita ini ke dalam film-filmnya sebagai bukti sebuah penghargaan akan dongeng klasik tersebut. Pada Maret 2017, film persembahan Walt Disney Pictures dan Madeville Films ini telah mengemas cerita tersebut menjadi sebuah tontonan berkonsep baru dari yang biasanya dengan bentuk film animasi. Kemasan yang diangkat berupa sebuah live-action version film, sebuah film nonanimasi yang kadang disebutkan berdasar atas perkembangan film animasi.

"Beauty and the Beast" ditulis oleh novelis berkebangsaan Perancis, GabrielleSuzanne Barbot de Villeneuve pada tahun 1740 dengan judul asli "La Belle et la Bête". Cerita rakyat klasik ini kemudian ditulis ulang dan dipublikasikan dengan versi pendeknya oleh Jeanne-Marie Leprince de Beaumont pada tahun 1756. Walaupun film "Beauty and the Beast" versi live-action ini bukan yang kali pertama dinikmati oleh masyarakat di dunia, alur ceritanya menarik banyak pemerhati film dan penulis untuk melakukan ulasan-ulasan, baik positif maupun negatif. Dari berbagai sudut pandang dan kajian sosial yang menyertainya, film ini telah berhasil memberikan gambaran akan sebuah cerita rakyat yang mengedepankan banyak aspek sosial yang terjadi, baik yang ditemui pada masa abad ke-18 maupun pada masa modern ini.

Sebagai bagian dari masyarakat dunia, penonton diajak untuk menengok kehidupan tokoh utama lewat film ini, Belle si Beauty dan Beast si pangeran tampan yang gagah berani. Belle diceritakan sebagai gadis yang sangat peduli pada pendidikan. Ia adalah gadis kutu buku yang peduli pada masyarakat di desanya yang belum melek huruf. Mengangkat fenomena-fenomena dan sudut-sudut pandang dari film tersebut, penelitian ini mengerucut pada pembahasan mengenai metafora pendidikan dan perkembangan sosioemosional tokoh utama. Fokus utama dari tulisan ini mengarah pada makna metafora pendidikan dalam masyarakat desa di tempat tokoh utama berinteraksi. Selain itu, akan dibahas pula aspekaspek sosial yang ditemui dalam masyarakat tersebut ketika pengaruh perkembangan sosioemosional tokoh utama mampu memberi pengaruh baik bagi gambaran dunia pendidikan pada masa itu. Analisis terhadap perkembangan sosioemosional tokoh utama menjadi inti bahasan dalam cerita "Beauty and the Beast" menjadi sang pembawa pesan bagi masyarakat.

\section{METODE PENELITIAN}

Jenis penelitian ini adalah kualitatif deskriptif, dengan merangkum data dari sumbersumber pustaka yang menjadi suatu informasi yang dapat diinterpretasi dan ditelaah. Tujuan penelitian ini adalah memberikan pemahaman makna metafora pendidikan yang tampak dalam alur cerita film "Beauty and the Beast" versi live-action serta analisis perkembangan sosioemosional tokoh utama yang menjadi 
pelaku pendidikan dan menerjemahkan konsep pendidikan yang sebenarnya bagi tataran struktur sosial masyarakat pada masa abad ke-18.

\section{PEMBAHASAN}

Lingkungan Pendidikan dan Persepsi Sosial terhadap Budaya

Lingkungan tempat masyarakat tinggal merupakan lingkungan yang secara tidak langsung akan memengaruhi banyak konsep pembelajaran dan pergaulan sosial di masyarakat. Lingkungan sosial kemudian membentuk suatu pemahaman akan konsep tersebut untuk menjadi berkembang ketika tiap individu berinteraksi dengan manusia lainnya. Interaksi tersebut kemudian membawa masyarakat kepada interaksi pendidikan. Menurut Sukmadinata (2011), interaksi pendidikan dipengaruhi oleh karakteristik pribadi dan corak pergaulan antarorang-orang yang terlibat dalam interaksi tersebut. Dari hasil interaksi antarpribadi tersebut kemudian timbul suatu lingkungan yang membedakan antara lingkungan intelektual dan lingkungan nilai.

Dari alur cerita yang digambarkan secara jelas dari film "Beauty and the Beast" dapat dilihat bahwa sebagian masyarakat di Perancis pada abad ke-18 tergolong masih terbelakang karena dampak dari Revolusi Perancis yang telah memengaruhi sistem politik dan sosial di negara itu. Oleh karena itu, digambarkan bahwa tokoh utama, Belle seorang gadis pintar, baik, kutu buku, dan pemimpi harus mengalami dampaknya ketika masyarakat di desanya secara terang-terangan menolak adanya perubahan dari sistem yang selama ini telah mereka miliki, yaitu kepada pendidikan modern. Konflik kelas yang muncul kemudian mengarah pada betapa lingkungan pendidikan sangat memegang peranan penting dalam perkembangan konsep pendidikan yang menjadi sorotan utama juga dalam cerita ini.

Persepsi sosial yang bisa ditemukan di lingkungan masyarakat adalah suatu proses menangkap arti objek-objek sosial dan kejadian-kejadian yang dialami dalam lingkungan itu sendiri (Mulyana, 2008). Menurutnya, setiap orang memiliki gambaran berbeda mengenai realitas di sekelilingnya. Hal ini dapat terlihat ketika sebagian masyarakat tempat tokoh utama dalam film "Beauty and the Beast" tinggal adalah masyarakat terbelakang dengan rata-rata penduduknya adalah petani dan pedagang. Masyarakat sederhana dengan pola pikir sederhana pula yang telah mengalami kepahitan hidup selama Revolusi Perancis di mana mereka tidak bisa menyuarakan hak dan prinsip hidupnya. Bergerak dari pendapat Mulyana, dapat disarikan bahwa persepsi sosial itu kemudian terikat oleh budaya masyarakat tempat Belle tinggal memaknai lingkungan tempat mereka tinggal berdasarkan nilai yang mereka anut. Nilai di sini adalah komponen evaluatif dari kepercayaan yang mencakup kegunaan, kebaikan, estetika, dan kepuasan. Inilah yang kemudian dimaksud dengan persepsi terhadap budaya (Mulyana, 2008).

Di dalam menilai suatu kebijakan, persepsi memegang peranan penting terhadap bagaimana sebuah pola pikir itu terbentuk. Borkowski (2005) pun menyampaikan bahwa "The person interprets the stimuli into something meaningful to him or her based on prior experiences. However, what an individual interprets or perceives may be substantially different from reality." Hal inilah yang terjadi, yakni adanya perbedaan pemahaman terhadap ajaran baru yang dikenalkan pada lingkungannya. Persepsi yang beberbeda ini memunculkan pertentangan dari berbagai pihak 
dalam menghambat pemahaman baru yang lebih modern. Belle, seorang gadis yang berasal dari keluarga berpendidikan, mengalami konflik karena mempunyai persepsi berbeda atas lingkungannya. Perbedaan persepsi tersebut bersifat subjektif yang menimbulkan perbedaan budaya antara Belle dan masyarakat di desanya yang kemudian mengarah pada perbedaan persepsi mereka terhadap realitas. Dari konteks tersebut, budaya dapat dianggap sebagai pola persepsi dan perilaku yang dianut sekelompok orang yang memiliki nilai yang normatif karena nilai ini mampu memberitahukan suatu anggota budaya mengenai apa yang baik maupun buruk, benar dan salah, siapa yang harus dibela, apa yang diperjuangkan, dan lain-lainnya (Mulyana, 2008).

Melalui analisis mengenai perbedaan persepsi yang berpengaruh pada referensi akan nilai-nilai yang ditemukan dalam masyarakat tempat Belle tinggal, muncullah pandangan bahwa lingkungan menjadi potensi penting dalam sebuah tujuan pendidikan. Tujuan pendidikan yang tidak lain salah satunya adalah untuk kepentingan masyarakat menjadi kabur ketika tidak ada motivasi dan dukungan dari lingkungan masyarakat itu sendiri. Menurut Sukmadinata (2011), sasaran dan perbuatan pendidikan selalu normatif, selalu terarah kepada yang baik dan tidak pernah diarahkan kepada pencapaian tujuan-tujuan yang merugikan atau bertentangan dengan kepentingan masyarakat. Namun bertolak belakang dari pendapat ini, masyarakat desa dalam alur cerita "Beauty and the Beast" sangat menentang suatu tujuan pendidikan untuk kemaslahatan dan kesejahteraan masyarakat. Dalam adegan saat Belle memberikan bimbingan kepada salah seorang anak untuk membaca agar dapat memiliki pengetahuan, hal ini ditolak mentah-mentah oleh masyarakat sendiri. Mereka berpendapat bahwa Belle membawa pengaruh buruk dengan memberikan ilmu baru, yaitu dengan membaca. Hal ini tidak lepas dari pandangan pendidikan pada masa Revolusi Perancis, yaitu telah terjadi peralihan politik dan sosial yang membawa dampak bagi masyarakat Perancis yang mengalami kemiskinan selama bertahun-tahun. Pada masa itu terdapat tiga golongan dalam masyarakat, yaitu golongan bangsawan, golongan agama, dan golongan rakyat jelata. Golongan rakyat jelata tidak mempunyai kesamaan hak seperti halnya golongan bangsawan dan agama yang mendapat perlakuan istimewa.

Dari wacana tersebut, dapat ditarik benang merah mengapa dalam alur cerita "Beauty and the Beast" ini golongan rakyat jelata sangat menentang adanya pembaruan yang diberikan oleh Belle melalui pendidikan. Trauma psikis akibat Revolusi Perancis dan tekanan sosial menjadi hal utama bagaimana masyarakat di desa Belle sangat menentang pengaruh baik dan modern. Belle yang tidak mendapat dukungan dari lingkungannya, tetap berpijak pada keyakinan diri bahwa dia telah melakukan perbuataan pendidikan. Lingkungan pendidikan yang ditemukan dalam masyarakat yang tidak didapatkan oleh Belle telah membuat dia menjadi sosok pribadi yang dewasa dan mandiri. Dia telah mendapat penguatan pendidikan dari lingkungan keluarganya walaupun tidak mendapatkannya dari lingkungan masyarakat tempat dia tinggal. Dengan statusnya sebagai sorang gadis remaja, dia tetap mengalami proses pendidikan dalam lingkungan masyarakat melalui kegiatankegiatan yang dia temui sehari-sehari dengan mempelajari problema-problema hidup yang dialami oleh sebagian besar masyarakat 
desanya. Hal ini didukung oleh pendapat Sukmadinata (2011) yang menyatakan bahwa pendidikan dalam lingkungan masyarakat lebih bersifat terbuka dan bahan yang dipelajari dapat mencakup seluruh aspek kehidupan, dengan sumber belajar yang ada dalam lingkungannya.

\section{Metafora Pendidikan}

Kehidupan sosial yang terlihat dari kegiatan sehari-hari masyarakat desa pemeran utama, Belle, menyuguhkan suatu kehidupan monoton dari golongan rakyat kelas bawah yang terhimpit oleh desakan ekonomi dan kesenjangan sosial antara dominasi kaum bangsawan dan kaum rakyat jelata. Dalam alur cerita film "Beauty and the Beast", kaum rakyat jelata ditampilkan sebagai rakyat yang menggemari pergunjingan, senang berkumpul, dan mudah sekali mendapat hasutan dari kaum dari golongan sosial yang lebih tinggi. Dari fenomena-fenomena tersebut timbul sebuah pertanyaan yang berkaitan dengan dunia pendidikan: apakah pendidikan pada masa itu hanya dipandang sebelah mata?

Tokoh utama, Belle, memiliki latar belakang kehidupan yang berasal dari keluarga berpendidikan. Ayahnya, Maurice, adalah seorang seniman dan juga seorang penemu yang mendukung anaknya untuk memperoleh pendidikan yang baik. Belle memperoleh pendidikan dari lingkungan keluarganya yang bukan dari kalangan rakyat biasa. Dari beberapa adegan dalam film "Beauty and the Beast”, penonton diajak untuk menganalisis makna dari kehidupan keseharian Belle dengan buku yang dia bawa ke mana pun dia pergi. Hal tersebut merupakan suatu tanda bahwa dia adalah seorang pribadi terpelajar dan memiliki impian tinggi untuk harapan-harapan yang ingin diraihnya. Dari wacana tersebut, muncullah pemahaman akan metaFora terhadap pendidikan di masa itu.

Istilah metafora kali pertama ditemukan oleh Aristoteles yang melihat kekuatan penalaran metaforis dalam kemampuannya untuk mengungkapkan konsep abstrak (Danesi, 2004). Aristoteles menyatakan bahwa sekuatkuatnya metafora secara konsep, fungsi utama metafora bersifat stilistik, yaitu merupakan alat untuk membuat cara berkomunikasi yang lebih prosais dan literal. Lebih lanjut lagi, seperti yang dikutip oleh Zheng dan Song (Zheng, Hong-bo, 2010), Moser mengemukakan pengertian metafora dalam sebuah pendidikan berguna untuk "accessing tacit knowledge and exploring social and cultural processess of understanding."

Berikut adalah sebuah diagram terhadap proses terbentuknya metafora pendidikan.

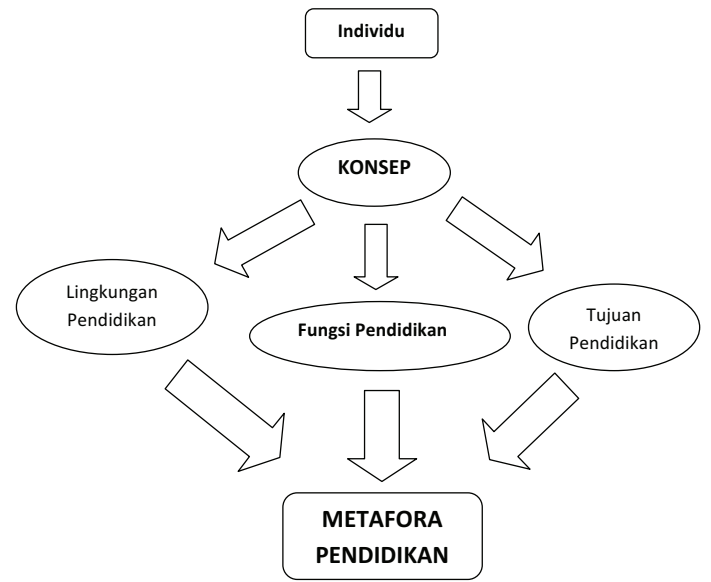

Alur Proses Terbentuknya Metafora Pendidikan Sumber: Olahan Penulis

Dari pemahaman akan metafora tersebut dapat dihubungkan dengan apa yang ditangkap dalam alur cerita film "Beauty and the Beast". Pendidikan dipandang sebagai sebuah metafora ketika dalam beberapa adegan menujukkan adanya suatu konsep abstrak terhadap makna pendidikan yang dapat dikaji dalam film, yaitu (a) adegan Belle ketika selalu membawa bukunya ke manapun dia berada; 
(b) adegan Belle mendatangi perpustakaan desa yang tidak pernah dikunjungi oleh orang lain selain dia; (c) adegan Belle memberikan pendampingan kepada anak kecil tetangganya untuk bisa membaca di tempat pencucian umum; (d) adegan Belle bersama Beast sang pangeran mengunjungi perpustakaan keluarga di dalam Kastil Beast; (e) adegan Belle dalam pengasingannya di dalam Kastil mendapat kesempatan meminjam buku untuk dia baca di kamar; dan (f) adegan Belle bersama Beast yang sangat antusias mendiskusikan sebuah buku.

Dari beberapa adegan tersebut, nyata bahwa pendidikan telah disampaikan dalam sebuah metafora. Hal tersebut dikuatkan oleh pendapat Danesi (2004) bahwa metafora menunjukkan suatu kecenderungan dasar dari pikiran manusia untuk memikirkan referen tertentu dengan cara tertentu. Lebih lanjut, dia mengungkapkan bahwa metafora merupakan bukti terkuat dalam eksistensi untuk mendukung apa yang disebut dengan prinsip saling terkait. Prinsip saling terkait ini dikatakan sebagai suatu kemampuan untuk mencari tahu dan membangun kesamaan di antara beberapa hal dan mengaitkannya secara semiotis. Secara paradoksal dan signifikan, metafora menjadi sedemikian fundamental dalam hal bagaimana membentuk abstraksi, seperti analogi, yang mengikutkan metafora.

Belle, yang tumbuh dan besar sebagai seorang gadis yang mengenal pendidikan dari lingkungan keluarganya, memahami fungsi pendidikan, yaitu untuk mengembangkan seluruh aspek pribadi secara utuh dan terintegrasi dengan pengembangan domain kognitif, afektif, dan psikomotor dalam pemilahannya (Sukmadinata, 2011). Hal tersebut nyata terlihat dalam beberapa adegan ketika Belle tidak memikirkan lebih jauh konsekuensi yang dia hadapi ketika masyarakat kebanyakan mengucilkan dan memandangnya sebagai gadis cantik tetapi aneh. Hal ini terjadi karena sebagian masyarakat di desanya tidak menyukai kebiasaannya akan membaca. Bahkan ketika seorang pemuda bernama Gaston yang dipandang oleh penduduk desanya adalah seorang yang dihormati menginginkan dia untuk menjadi istrinya, Belle tetap pada keyakinannya bahwa dia mempunyai harapan tinggi untuk mendapatkan laki-laki sejati yang memiliki integritas dan kepandaian yang tidak dimiliki oleh Gaston yang telah memiliki segalanya.

Dari acuan alur terbentuknya metafora pendidikan dan disandingkan dengan beberapa adegan film dalam mengungkap makna pendidikan, tampak jelas bahwa metafora pendidikan yang tergambar dalam film "Beauty and the Beast" adalah sebuah manifestasi konsep terhadap apa yang dipahami sebagai sebuah tindakan mendidik yang mendapat pertentangan dari lingkungan namun yang justru menguatkan individu, yaitu tokoh utama, Belle untuk terus mengalami proses pengembangan kognitif dan afektifnya.

\section{Perkembangan Sosioemosional}

Terdapat dua teori utama yang membahas perkembangan sosioemosional anak, yaitu teori ekologi Bronfenbrenner dan teori perkembangan rentang kehidupan Erikson. Kedua teori ini sangat mendukung dalam menganalisis sudut pandang pemahaman akan kehidupan tokoh utama dalam film "Beauty and the Beast" ini. Menurut Santrock (2008), teori ekologi yang dikembangkan oleh Bronfenbrenner berfokus pada kontekskonteks sosial tempat anak-anak tinggal dan orang-orang yang memengaruhi perkembangan mereka. Adapun teori perkembangan rentang 
kehidupan Erikson memberikan pandangan perkembangan mengenai kehidupan orangorang dalam tahapan-tahapan yang melengkapi analisis dari Bronfenbrenner.

Berikut ini adalah kedua teori yang mendukung perkembangan sosioemosional, yaitu sebagai berikut.

\section{Teori Ekologi Bronfenbrenner}

Teori ini terdiri atas lima sistem lingkungan, dari hubungan interpersonal yang kuat sampai pengaruh budaya internasional. Lima sistem tersebut adalah mikrosistem, mesosistem, eksosistem, makrosistem, dan kronosistem (Santrock, 2008).

a. Mikrosistem, adalah lingkungan tempat individu menghabiskan banyak waktu, seperti keluarga, teman sebaya, sekolah, dan lingkungan di sekitarnya. Dalam mikrosistem ini individu tersebut berinteraksi langsung dengan orang tua, teman sebaya, dan lainnya. Dia menerima pengalaman yang aktif dan berinteraksi secara timbal balik dengan orang lain dan dia membantu membentuk mikrosistem.

b. Mesosistem melibatkan hubungan antar mikrosistem. Misalnya, hubungan antara pengalaman keluarga dan teman sebaya serta antara keluarga dan lingkungannya.

c. Eksosistem berfungsi ketika pengalaman di keadaan lain di mana individu tidak memiliki peran aktif yang memengaruhi apa yang dialami individu tersebut dalam konteks terdekat. Misal, kepala perpustakaan dan rak-rak buku yang kosong yang akan memberikan peranan kuat dalam menentukan kualitas perpustakaan itu sendiri.

d. Makrosistem melibatkan budaya yang lebih luas, yang mencakup peran faktor etnis dan faktor sosioekonomi dalam perkembangan individu. Status sosioekonomi, sebuah aspek budaya yang penting, bisa mempunyai pengaruh yang penting terhadap prestasi individu. Misal, kemiskinan bisa mengganggu perkembangan individu dan menghalangi kemampuan mereka untuk belajar, walaupun beberapa individu dalam keadaan miskin mampu berkembang dengan baik.

e. Kronosistem mencakup kondisi sosiohistoris dari perkembangan tiap individu. Misal, kehidupan anak-anak zaman sekarang akan sangat berbeda dalam banyak hal dibandingkan dengan zaman kakek nenek pada zaman dahulu.

Teori Bronfenbrenner ini memberikan kerangka untuk menelaah konteks sosial secara sistematis, baik pada level mikro maupun makro, menjembatani antara teori perilaku yang berfokus pada hal kecil dan teori antropologi yang menganalisis hal yang lebih besar. Namun demikian, teori ini tidak terlalu memerhatikan faktor biologis dan faktor kognitif dalam perkembangan individu dan tidak membahas perkembangan secara bertahap (Santrock, 2008).

2. Teori Perkembangan Rentang Kehidupan Erikson

Teori ini membahas delapan tahap perkembangan manusia. Setiap tahap terdiri atas tugas perkembangan yang 
mempertemukan individu dengan sebuah krisis. Menurut Erikson, krisis bukan merupakan sebuah bencana, melainkan titik balik dari kerentanan yang semakin meningkat dan potensi yang semakin meninggi. Semakin berhasil individu menyelesaikan suatu krisis, semakin sehat individu tersebut secara psikologis.

a. Kepercayaan (trust) versus ketidakpercayaan (mistrust), adalah tahapan psikososial pertama yang muncul pada tahun pertama kehidupan. Kepercayaan dapat berkembang dengan baik ketika anak tumbuh dalam kehangatan dan kasih sayang yang cukup.

b. Otonomi (autonomy) versus rasa malu dan ragu (shame and doubt), tahapan psikososial kedua yang muncul pada akhir masa bayi dan usia toddler. Setelah mendapatkan kepercayaan dari pengasuh mereka, bayi mulai mengetahui bahwa perilaku mereka adalah wajar. Mereka menyatakan kebebasan dan dan menyadari kehendak mereka.

c. Inisiatif (initiative) versus rasa bersalah (guilt), adalah tahapan psikososial ketiga yang sesuai dengan masa kanak-kanak awal, yaitu sekitar usia tiga sampai lima tahun. Seiring dengan banyaknya pengalaman dalam lingkungan sosial, anak-anak dituntut untuk terlibat dalam perilaku yang aktif dan memiliki tujuan. Dalam tahap ini orang dewasa mengharapkan anak-anak untuk menjadi lebih bertanggung jawab atas diri sendiri dan barang kepunyaan mereka karena mengembangkan rasa tanggung jawab akan meningkatkan inisiatif.

d. Rajin (indistry) versus rendah diri (inferiority), adalah tahapan psikososial keempat yang sesuai dengan masa sekolah dasar, dari usia enam tahun sampai pubertas atau masa remaja awal. Inisiatif akan membawa mereka ke dalam berbagai pengalaman baru. Di usia ini mereka mengarahkan energi mereka untuk menguasai ilmu pengetahuan dan keterampilan intelektual.

e. Identitas (identity) versus kebingungan identitas (identity confusion) adalah tahapan psikososial kelima yang sesuai dengan masa remaja. Remaja berusaha untuk mencari tahu diri mereka, seperti apakah mereka, dan ke mana tujuan hidup mereka. Mereka dihadapkan kepada peran baru dan status orang dewasa. Mereka diharapkan mendapatkan kesempatan untuk mengeksplorasi jalan-jalan yang berbeda untuk membentuk identitas mereka.

f. Keintiman (intimacy) versus isolasi (isolation) adalah tahapan psikososial keenam yang sesuai dengan masa dewasa awal, yaitu usia dua puluhan dan tiga puluhan. Tugas perkembangannya adalah membentuk hubungan yang positif dengan orang lain. Erikson mendeskripsikan keintiman bukan hanya sebagai penemuan diri sendiri, 
tetapi meleburnya diri sendiri dalam diri orang lain.

g. Generativitas (generativity) versus stagnasi (stagnation) adalah tahapan psikososial yang ketujuh yang sesuai dengan masa dewasa menengah, yaitu usia empat puluhan dan lima puluhan. Generativitas berarti memindahkan sesuatu yang positif ke generasi berikutnya yang melibatkan peran-peran seperti menjadi orang tua dan guru di mana mereka membantu generasi berikutnya dalam mengembangkan kehidupan yang berguna.

h. Integritas (integrity) versus keputusasaan (despair) adalah tahapan psikososial kedelepan yang sesuai dengan masa dewasa akhir, yaitu usia enampuluh tahunan sampai kematian. Orang dewasa yang lebih tua meninjau kembali kehidupan mereka dan merenungkan apa yang telah mereka lakukan. Apabila evaluasi masa lalu ini positif, mereka mengembangkan rasa integritas, yang artinya mereka memiliki integritas yang positif dan layak dijalani.

Teori Erikson menggunakan beberapa tugas sosioemosional yang penting dalam kehidupan dan menempatkannya dalam kerangka perkembangan. Seluruh teorinya merupakan suatu kekuatan yang penting dalam menempa pandangan saat ini, tentang perkembangan manuasia yang kekal daripada yang dibatasi hanya pada masa kanak-kanak.

\section{Metafora Pendidikan dan Sosioemosional Tokoh Utama}

Pembahasan ini akan mengacu pada makna dari metafora pendidikan dan persepsi yang timbul ketika soerang gadis muda melakukan kegiatan pendidikan bagi masyarakat di desanya serta bagaimana dia merespons makna pendidikan itu sendiri bagi perkembangan sosioemosionalnya sebagai kaum terpelajar yang terbelenggu oleh pertentangan yang terjadi di masyarakat karena adanya kesenjangan status sosial. Metafora pendidikan yang telah dikemukakan sebelumnya akan bersanding dengan teori Gestalt yang merupakan suatu pandangan kognitif awal yang menentang banyak asumsi behaviorisme. Teori ini memberikan prinsipprinsip penting yang banyak dijumpai dalam konsepsi persepsi dan pembelajaran di zaman ini (Schunk, 2012). Teori ini pada awalnya berlaku untuk persepsi, namun pengikutpengikutnya menemukan fokusnya pada pembelajaran. Menurut pandangan Gestalt, pembelajaran merupakan fenomena kognitif yang melibatkan pengorganisasian ulang pengalaman-pengalaman menjadi persepsipersepsi yang berbeda-beda dari benda-benda, orang, atau peristiwa-peristiwa (Schunk, 2012). Sebagian besar proses belajar manusia melibatkan banyak pemahaman baru, yang berarti bahwa transformasi dari tidak tahu ke tahu itu terjadi dengan cepat.

Teori Gestalt sangat merespons keberadaan metafora pendidikan yang menjadi pengalaman Belle dalam usahanya mentranformasikan kebutuhan sebagian masyarakat penduduk desa akan pendidikan. Hal terutama adalah bagaimana masyarakat ini dapat melek huruf. Pertentangan yang dialami oleh Belle berakibat pada sebuah persepsi 
pribadi yang dimiliki Belle dalam memandang suatu pengaruh kognitif sebagai bagian dari proses terjadinya pendidikan.

Kedua teori perkembangan sosioemosional yang telah disampaikan sebelumnya mengarahkan pada konteks perkembangan sosial yang terjadi terutama dalam kehidupan Belle. Menurut teori Bronfenbrenner, konteks sosial tempat individu tinggal merupakan hal penting yang mempengaruhi perkembangan mereka. Belle telah mengalami proses perkembangan itu sendiri bersama dengan keluarga, teman sebaya, dan sekolah. Dikaji dari teori ekologi Bronfenbrenner, dia mendapat dukungan dari ayahnya, pustakawan di desanya, dan Beast. Kesemuanya ini terlibat dalam mikrosistem, mesosistem, dan makrosistem yang sangat mendukung perkembangan sosioemosional Belle sebagai individu. Ditinjau dari teori perkembangan rentang kehidupan Erikson, perkembangan sosioemosional Belle melibatkan beberapa tahap, yaitu dari tahap psikososial yang pertama hingga keenam yaitu, tahap kepercayaan, otonomi, inisiatif, rajin, identitas, dan keintiman.

Teori-teori perkembangan sosioemosional yang dialami oleh Belle mendapat dukungan dari konsep diri dan hubungan antara budaya dan gaya belajar. Konsep diri ini adalah suatu keyakinan individu terhadap dirinya sendiri (Bennet, 2003). Konsep diri ini memengaruhi sikap kita yang kemudian juga mempengaruhi bagaimana orang lain melihat diri dan memperlakukan kita. Sehingga pada akhirnya keterikatan itu menjadi lengkap. Belle yang digambarkan sebagai sosok gadis cantik yang mempunyai impian dan keinginan besar untuk mencapai cita-cita telah terungkap melalui buku-buku yang telah ia baca secara pribadi dan bersama dengan Beast. Beast merespons kebutuhan Belle akan ilmu pengetahuan, yaitu dengan memberikan kesempatan sebesarbesarnya kepada Belle untuk mengeksplorasi perpustakaan keluarga Beast yang telah lama ditelantarkan. Sayangnya, hal ini mendapat respons negatif dari penduduk desa yang buta huruf dan tidak berpendidikan. Mereka menganggap bahwa apa yang telah dilakukan Belle adalah hal yang bodoh dan tidak berguna. Menurut mereka hidup adalah untuk bekerja bukan hanya dengan membaca dan bermimpi.

Hubungan antara budaya dan gaya belajar tentu saja juga sangat memberi pengaruh kepada perkembangan sosioemosional Belle. Menurut Worthley dalam Bennet (2003), ada lima faktor budaya yang muncul untuk memberikan pengaruh bagi gaya belajar, yaitu proses sosialisasi, keeratan sosiokultural, faktor adaptasi ekologi, pengaruh biologis, dan kecakapan bahasa yang memberi pengaruh penting terhadap gaya belajar. Dari kelima faktor tersebut, Belle mengalami kelima hal tersebut dalam prosesnya mendapatkan gaya belajar yang dia yakini yang paling tepat setelah dia mengkaji fenomena-fenomena sosial yang terjadi di masyarakat desanya. Dia seolah tidak peduli terhadap apa yang sebagian orang katakan mengenai dirinya sebagai kutu buku dan orang aneh. Dia hanya mengalami perkembangan sosioemosional yang berhubungan dengan konsep dirinya dan budaya yang terdapat di desa tempat tinggalnya.

\section{SIMPULAN}

"Beauty and the Beast" mengungkapkan keprihatinan masyarakat pada masa itu dalam hal pendidikan. Penggambaran kondisi pendidikan masyarakat saat itu terlihat jelas dengan metafora pendidikan melalui harapan dan kegiatan yang dilakukan sang 
tokoh utama. Teori Gestalt sangat merespons keberadaan metafora pendidikan yang menjadi pengalaman tokoh utama dalam usahanya mentranformasikan kebutuhan sebagian masyarakat penduduk desa akan pendidikan. Metafora pendidikan digambarkan secara jelas oleh tokoh utama dalam kaitannya dengan buku, perpustakaan, pendampingan membaca, dan book discussion. Dalam sisi sosioemosional, mikrosistem, mesosistem, dan makrosistem menjadi satu rangkaian proses perkembangannya bersama dengan aspek psikososialnya, yaitu kepercayaan, otonomi, inisiatif, rajin, identitas, dan keintiman.

\section{KEPUSTAKAAN}

Bennet, C. I. (2003). Comprehensive Multicultural Education: Theory and Practice (5th Ed). Boston: Pearson Education, Inc.

Borkowski, N. (2005). Organizational Behavior in Health Care. canada: Jones and Bartlett Publishers.

Danesi, M. (2004). Messages, Signs, and Meanings: A Basic Textbook in Semiotics and Communication Theory (3rd Ed.). canada: Canadian Scolars' Press Inc.

Mulyana, D. (2008). Ilmu Komunikasi: Suatu Pengantar. Bandung: PT. Remaja Rosdakarya.

Santrock, J. W. (2008). Educational Psychology (3rd Ed.). New York: McGraw-Hill.

Schunk, D. H. (2012). Learning Theories: An Educational Perspective (6th Ed.). Boston: Pearson Education, Inc.

Sukmadinata, N. S. (2011). Landasan Psikologi Proses Pendidikan. Bandung: PT. Remaja Rosdakarya.

Zheng, Hong-bo, W.-J. S. (2010). Metaphor Analysis in the Educational Discourse: A Critical Review. US-China Foreign Language, Vol 8 No 9(September 2010). 